\title{
The maturity of rail freight logistics service providers in Brazil
}

\author{
Adauto Farias Bueno ${ }^{\mathrm{a} *}$, Luciana Hazin Alencar ${ }^{\mathrm{b} * *}$ \\ aniversidade do Estado de Mato Grosso, Barra do Bugres, MT, Brazil \\ bUniversidade Federal de Pernambuco, Recife, PE, Brazil \\ *adauto.bueno@unemat.br, **alencarlh@gmail.com
}

\begin{abstract}
This study analyzes the maturity of three rail freight Logistics Service Providers (LSPs) in Brazil in a population of seven operators. After an exploratory review of the existing literature and research documents, a structured questionnaire based on the Supply Chain Capability Maturity Model S(CM) ${ }^{2}$ was applied. The study measured an overall average level, given in $\mathrm{S}(\mathrm{CM})^{2}$, as Managed, meaning that the managerial development standard of the logistics agents was at an intermediate level. The results showed that maturity was related to the size of the LSP and the complexity of the organizational management. These findings can support the development of policies and strategies for the improvement and adoption of practices that best lead to gains in competitiveness for both LSPs and the Supply Chains (SCs) that require their services.
\end{abstract}

Keywords

Supply Chain capability maturity model $\mathrm{S}(\mathrm{CM})^{2}$. Rail freight. Logistics service providers.

\section{Introduction}

The Logistics Service Providers (LSP) industry has been growing and gaining in importance both private and governmental strategies. This fact results in great demands and challenges concerning the physical flow and management of the many logistics systems and supply chains that are emerging from clusters of production in Brazil.

According to Lang (2007), Brazil spends an average of $\mathrm{R} \$ 1$ billion more each year for lack of adequate transport charges. Then, there is an infrastructure deficit in two strategic transport operations - Rail and Waterways. In countries of continental dimensions that have most of the products based on commodities and primary products (agricultural products, minerals), both mentioned transportation modes are based on the economy of logistics costs.

According to Rossi (2013), logistics costs represented $10.9 \%$ of the Gross Domestic Product (GDP) in 2008, 10.6\% in 2010 and 11.5\% of the GDP in 2012 (R\$ 507 billion). This percentage represents a return to the 2006 level. 142 PSLs operating in Brazil have together, in 2011, net revenues of $\mathrm{R} \$ 48$ billion, which is about $20 \%$ higher than the previous year.
The sector has more than US $\$ 400$ billion with logistics costs, representing about 10\% of the national GDP.

Transportation is the most costly one, with 7.1\% ( $R \$ 312.4$ billion) of the logistics costs in proportion to GDP. It was the highest percentage since 2004 when it represented $7.5 \%$. The cost of transport consists of items such as the price of diesel, toll, and insurance. Expenses related to stock (3.2\%), storage $(0.8 \%)$ and administrative costs $(0.4 \%)$ are also considered in the total account of total logistics costs in the country (Rossi, 2013).

The first version the National Transport Logistics Plan of Brazil foresaw an investment of $\mathrm{R} \$ 291$ billion until 2025. In a reformulation of this proposal, this amount of investment changed to US $\$ 428$ billion until 2035, through the participation of Transport Ministry and National Bank for Economic and Social Development (BNDES). These efforts have as main purpose to increase from $26 \%$ to $35 \%$ the participation of the rail sector in the matrix composition (Associação Nacional dos Transportadores Ferroviários, 2010). 
Then, the railroad sector, specifically the freight sub-sector, has undergone, in recent years, a substantial transformation due to the reshaping of economic and productive activity in Brazil. This situation has made viable to create alternative logistics. If the LSPs are efficient, multimodal and integrated (physically and managerially), those can play a central role in enhancing the provision of customer services to many supply chains that operate in Brazil. Many of these LSPs could improve their performance evaluating their maturity.

As McCormack et al. (2009) state, maturity is when processes move from a development perspective internally focused to externally focused perspective of the system. According to McCormack et al. (2009), Cooke-Davies \& Arzymanow (2003), CMM1 (Capability Maturity Model Integrated, 2011) and Estampe et al. (2013), the Software Capability Maturity Model (CMM) for software organizations was the pioneer in efforts to assess the maturity of processes.

Companies whose businesses are within the supply chain did not remain aloof from process capability models and began to use them. Most of them use in an adapted way, in order to assess the operational and managerial capability of their suppliers, partners, customers and outsourced service providers. That is, to any agent with whom they maintain a business relationship anywhere on the supply chain, with a view to leveraging and ensuring competitive advantage and creating value (Goldenson \& Gibson, 2003).

At the same time that this adaptive process of the theory of process maturity from the perspective of supply chains and logistics was taking place, in practice, organizations worldwide and, more recently,
Brazilian ones, have started to focus on significantly increasing profitability. They adopted best practices, learned and summarized the state of the art, thus leveraging a certain development in operations and logistics management (evolution towards maturity). Thus, they make efforts to develop a managerial function that is vital for organizations if they are to compete in global markets (McCormack et al., 2008).

A decisive factor that conditioned organizations search for greater performance from business and operational processes was that of Brazil entering into an era of significant economic, productive and organizational changes. The scenario of Brazilian economic growth in recent years has generated a new reality of investments and demands for solutions to problems in all areas related to national production. It happens especially in the logistics sector. It has a direct interest in supporting the processes needed to upgrade the transport infrastructure, in order to enhance the operation of many supply chains structured in the matrix of national production. Thereby, to provide global markets with the most diverse products.

All these transformations have converged and led to a significant increase in the number of logistics agents dedicated to solutions or simply to their being able to carry out basic logistics operations. In this study, these agents are called Logistics Service Providers (LSPs) and are limited to the Brazilian rail freight sector.

There have been many studies on the performance of LSPs within the Supply Chain (SC) since the 1990s, applied in several studies, as specified in Table 1.

Table 1. Studies regarding Logistics Service Providers.

\begin{tabular}{|c|c|}
\hline Research subject & Literature (authors) \\
\hline Logistic Performance and LSP companies benchmarking & $\begin{array}{l}\text { Lai (2004) } \\
\text { Min \& Joo (2006) } \\
\text { Fugate et al. (2010) } \\
\text { Hofmann \& Lampe (2013) } \\
\text { Bai \& Sarkis (2013) } \\
\text { Guarnieri et al. (2014) }\end{array}$ \\
\hline Innovation of Logistics services by the LSP & $\begin{array}{l}\text { Flint et al. (2005) } \\
\text { Daugherty et al. (2011) } \\
\text { Wagenstetter et al. (2013) }\end{array}$ \\
\hline Logistics, marketing and LSPs & $\begin{array}{l}\text { Knemeyer \& Murphy (2004) } \\
\text { Lieb \& Lieb (2008) } \\
\text { Huemer \& Furlan (2013) }\end{array}$ \\
\hline Economy of transaction costs in the supply chain in the view of the LSP & $\begin{array}{l}\text { Ellram et al. (2008) } \\
\text { Zacharia et al. (2011) } \\
\text { Leuschner et al. (2014) }\end{array}$ \\
\hline Selecting logistics providers & $\begin{array}{l}\text { Wanke et al. (2007) } \\
\text { Vivaldini et al. (2013) } \\
\text { Kafa et al. (2014) }\end{array}$ \\
\hline The relationship between LSP organizations and environmental sustainability and social & $\begin{array}{l}\text { Lieb \& Lieb (2010) } \\
\text { Kudla \& Klaas-Wissing (2012) } \\
\text { Colicchia et al. (2013) } \\
\text { Kafa et al. (2014) }\end{array}$ \\
\hline
\end{tabular}


No recent studies on maturity in LSP agents were found, thus revealing a gap in the literature.

Research about LSP is as dynamic as the industry itself. From this point of view, one of the recent studies that stands out is that by Zacharia et al. (2011). They used a resource-based vision, network theory and economy transaction costs, to develop a model that established constructs that serve as a reference. Then, executives of client organizations and other stakeholders can define a Logistics Service Provider as a leading orchestrator of the supply chain. They can define the logistics agent who has the role of governing the activities of management, coordination and creating value in networks and in supply chains strategically, among different members.

Bai \& Sarkis (2013) emphasize the absence of literature regarding models for evaluating flexibility of operations and management of reverse logistics concerning the role of LSP in the practices of reverse supply chains, due to the inherent variance and uncertainty. These authors use Third Party Reverse Logistics Providers (3PRLP) as the same mean of our use of LSP in the present study. Their study proposes a framework for evaluation and support to decisionmaking for the development and maturity of the flexibility of the 3PRLP as logistics organizations. They use the performance evaluation of the variable flexibility in the operational (flexibility in logistics activities) and strategic dimensions (flexibility regarding changes in the supply chain and on the organizational structure).

Other studies regarding maturity of 3PRLPs were not found. Most of the studies developed focus on specific variables, like those highlighted in Table 1 for LSPs in its generic form. Guarnieri et al. (2014) presented findings of particular models. They studied the decision-making regarding selection of 3PRLP in Brazil, using multicriteria decision aid methodology. Kafa et al. (2014) focused the selection of 3PRLP based on the sustainability criterion, applying multicriteria methodology with fuzzy logic.

Then, as to understand LSPs activities and their relationships in the context of logistics and SC processes, there is a need to give a brief account of how outsourcing affected Supply Chain Management (SCM). It is against this background that arises the problem of the development and maturity of LSPs that provide rail freight services in Brazil, by means of their adopting the best practices in SCM. By applying the "Supply Chain Capability Maturity Model", this research sets out to explore the current level of maturity at which the Service Providers of Rail Freight Logistics (concessionaires) in Brazil are. It was conducted an evaluation in six distinct functional areas (visions) that specify the overall level of maturity of each LSP studied. The adoption and the development of best practices by the companies surveyed are discussed.

The paper is structured into six sections, in addition to this Introduction. Section 2 presents the conceptual basis of the model on the Maturity of Logistics and Supply Chain Management, and the models derived from it. Section 3 sets out the methodological developments that guided the study. Section 4, Results, gives a detailed presentation of the results gathered on the maturity of each LSP studied. Section 5 presents the discussion of the results. Finally, Section 6 presents the Conclusions on the profile of the overall maturity of the rail freight sub-sector from the perspective of the LSP evaluated.

\section{Maturity models in the Supply Chain and Logistics}

Models of measurement and evaluation of the variable performance were, at the time, more exploited than those dedicated to the study of other isolated areas of Logistics and SC, and further explored than models of systemic evaluation (multi-level stages, multi-variables and multi-dimensional) of agents and processes (Frederico \& Martins, 2012). A confirmation of this vast literature related to the variable performance comparing with other components of Logistics and SC can be found in Estampe et al. (2013), which presents a review of 16 models of performance measurement and evaluation. Some of them, Estampe et al. (2013), as SCOR metrics, for example, have significantly influenced some current models for measuring and assessing the maturity of supply chain and logistics (Table 2). Additionally, models to evaluate the maturity in quality management, as the grid Crosby (1979), the capability of processes and maturity of software - CMM/CMMI (Capability Maturity Model Integrated, 2011) and maturity models for project management (Cooke-Davies \& Arzymanow, 2003) have also exerted influence in those maturity models for logistics and SC.

Reyes \& Giachetti (2010) and Giachetti (2010) point out that in the field of SCM, many studies have been carried out, defined and restricted under the vision of the operations of this SC. Some conceived from the perspective of information technology, others under the vision of the conception of business processes, of inventory management, and so on.

Therefore, making decisions about improvements in the SC without proper interdisciplinary analysis can lead to disastrous decisions, resulting in time and money being wasted and loss of market position. For these reasons, there is a need for guidelines based 
on best practice models that have been successfully applied (Reyes \& Giachetti, 2010).

The maturity assessment model used in this research is the Supply Chain Capability Maturity Model - S(CM) ${ }^{2}$. This model was chosen considering the interdisciplinary character of the model (evaluation of multiple points of view) and its measurement character and overall LSP evaluation. Each point of view is analyzed, and the level of overall maturity of each LSP is obtained by the average of the six points of view considered in the model.

Table 2 presents a brief overview of the main models concerning the maturity of Logistics and SCM.

\section{Research approach}

The technical procedure adopted in this research is a survey (as Figure 1). Miguel \& Ho (2012) emphasize that surveys studies have as purpose to generate contributions to a particular knowledge area; in this case, knowledge about logistics maturity of rail freight agents in Brazil. Then, the survey of this research is exploratory, with the goal of providing initial knowledge about a subject, proposing foundations for a more detailed survey in the future.

The survey of the present study is based on the $\mathrm{S}(\mathrm{CM})^{2}$ model structure, with a non-probabilistic sampling

Table 2. Maturity models regarding supply chain and logistics.

\begin{tabular}{|c|c|c|}
\hline Model & Author & Conceptual Orientation \\
\hline $\begin{array}{l}\text { Model by Christopher (2007) for Integrated Logistics } \\
\text { (Adapted from Stevens, 1989) }\end{array}$ & Christopher (2007) & $\begin{array}{l}\text { Staged, but without adopting the principle of } \\
\text { process capability. It leaves a gap about the } \\
\text { metrics for measuring maturity. }\end{array}$ \\
\hline Business Process Orientation Maturity Model & Lockamy 111 \& McCormack (2004) & $\begin{array}{l}\text { Staged, governed by the principle of process } \\
\text { capability and the vision of business processes. } \\
\text { it uses SCOR metrics. }\end{array}$ \\
\hline Supply Chain Maturity Model & $\begin{array}{l}\text { PRTM Management Consultants/ } \\
\text { PMG (Project Management Group, } \\
\text { 2003) }\end{array}$ & $\begin{array}{l}\text { Staged, governed by the principle of process } \\
\text { capability and the practical, functional vision } \\
\text { of the organizational world. It is simple to } \\
\text { understand and apply. It uses SCOR metrics. }\end{array}$ \\
\hline $\begin{array}{l}\text { Computer Sciences Corporation Framework } \\
\text { (See Poirier et al., 2009) }\end{array}$ & CSC Corporation & $\begin{array}{l}\text { Staged, governed by the principle of process } \\
\text { capability. A framework for assessing } \\
\text { organizational performance can be adapted to } \\
\text { logistics and SC. 1t uses SCOR metrics. }\end{array}$ \\
\hline Supply Chain Capability Maturity Model- S(CM $)^{2}$ & Reyes \& Giachetti (2010) & $\begin{array}{l}\text { Staged, governed by the principle of process } \\
\text { capability. It uses a multi-vision, integrated } \\
\text { approach at decision-making levels. It is } \\
\text { specific for assessing maturity in the SC. }\end{array}$ \\
\hline $\begin{array}{l}\text { Model for alignment between performance } \\
\text { measurement systems and maturity of supply chain } \\
\text { management }\end{array}$ & Frederico \& Martins (2012) & $\begin{array}{l}\text { Staged, based on the integration of the } \\
\text { methodology for maturity assessment of } \\
\text { Lockamy } 111 \text { \& McCormack (2004) with the } \\
\text { methodology of performance measurement } \\
\text { systems of Wettstein \& Kueng (2002). }\end{array}$ \\
\hline $\begin{array}{l}\text { Supply Chain Process Management Maturity } \\
\text { Model - (SCPM3) }\end{array}$ & Trkman et al. (2012) & $\begin{array}{l}\text { Based on the Business Process Orientation } \\
\text { Maturity Model with the integration of } \\
\text { Business Analytics tool. }\end{array}$ \\
\hline
\end{tabular}

Source: Elaborated by the authors (2015).
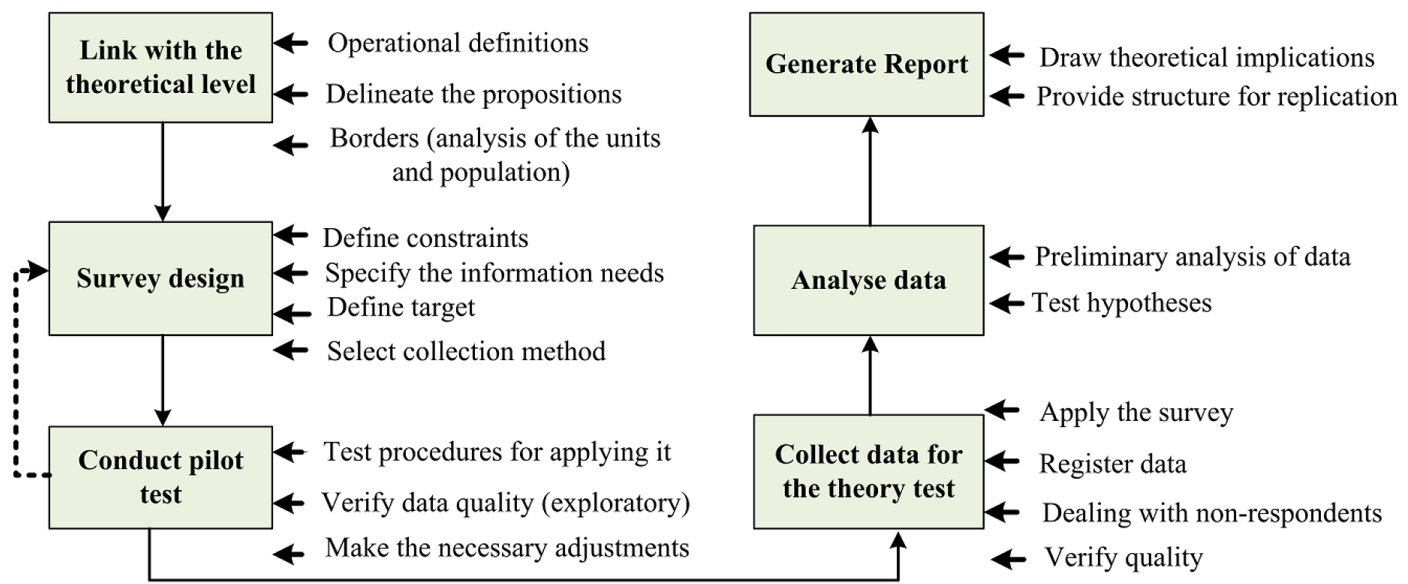

Figure 1. Methodological systematic for conducting a survey. Source: Miguel \& Ho (2012). 
procedure. The sample size is $n=3$ (3 LSPs), with a population size of $\mathrm{N}=7$ (the 12 public concessions in Brazil are operated by 7 LSPs). The data collection instrument was a questionnaire with 170 questions divided into six views on the maturity of Logistics and SC. A systematic approach proposed by Forza (2002) and adapted by Miguel \& Ho (2012) guided the present research (Figure 1).

\subsection{Operationalizing the systematic}

In this section, the systematic chosen to guide the methodological procedures in this study is presented. The systematic adopted provided the reliability required when using the survey method.

First, a review of the literature regarding the main models for assessing maturity throughout the $\mathrm{SC}$ was carried out. The mapping, setting of the borders, and the degree of evolution of studies on the construct of the Maturity of an LSP are presented, pointed to the lack of a specific model for evaluating maturity. Few existing models were developed for specific industrial companies, which leads to specific evaluation metrics and visions arising. Thus, there is no model developed exclusively for assessing the maturity of agents throughout the SC.

The model found in the literature that most closely fill this gap was the S(CM) ${ }^{2}$ of Reyes \& Giachetti (2010). It was chosen and applied in this study. However, the component visions were adapted to evaluate LSP companies.

Planning the survey followed the systematic sections of Figure 1. Firstly, the units of analysis of the cases and the contacts were selected. Then, the instruments for data collection were chosen, viz., a standard protocol for data collection. Finally, ways to control the research were developed.

The sub-sector of rail transport in Brazil consists of a population of 7 operators in railway concessions loads. They have 12 public concessions that comprise the object of this study. There are another four industrial railroads that exclusively serve specific projects, under the system of authorization, and permission to construct and to operate railroad services, which are also included in the regulatory framework for the sector.

The selection of units of analysis for the survey study was determined in order to choose what Forza (2002) describes as typical elements of the population. Therefore, three representative LSPs were selected to investigate the problem: two concessionaires of the South region of Brazil (LSP A and LSP B), and one from the Southeastern region (LSP C).

The research followed the logic of the $\mathrm{S}(\mathrm{CM})^{2}$ model. The potential respondents from each participating concessionaire should occupy a management position and/or have an extensive experience in the professional activities of their company.

The parties incorporated were the six functional areas adapted from the original seven visions of the $\mathrm{S}(\mathrm{CM})^{2}$ model. The new visions adopted are: i) Management of Suppliers (GFOR); ii) Management of Production System Services (GPSL); iii) Management of Transport, Inventory and Storage (GETA); iv) Management of Information Technology (GSIT); v) Management of Performance Measurement Systems (GSMD); and $v i$ ) Management of Human Resources (GRHU).

A questionnaire based on the $\mathrm{S}(\mathrm{CM})^{2}$ was drawn up according to the best practices found in the literature, as per the 6 component visions adapted from the model by Reyes \& Giachetti (2010). First, a selection was made to compile each group of questions for the questionnaire, which corresponds automatically to each vision of the $\mathrm{S}(\mathrm{CM})^{2}$ model based on best practices (e.g. Group 1, Table 3). They were listed in an extension of well-respected references that are relevant to understanding the maturity of each organizational area within each concessionaire.

The second instrument of data collection was Documental Research for in-depth investigation and analysis of the maturity of the LSPs and to cross-check the evidence. This research was prepared with documents from official agencies in Brazil and institutions linked to logistics such as the Ministry

Table 3. Group of practices related to the group of questions regarding supplier management and their codification.

\begin{tabular}{llll}
\hline \multicolumn{1}{c}{ Control Variable } & \multicolumn{1}{c}{ Evaluated practices } & References \\
\hline & $\begin{array}{l}\text { Documentation, standardization, selection and improvement projects for } \\
\text { operations and management regarding the suppliers; incentive policies and } \\
\text { monitoring the planning and control of suppliers' production; Statistical }\end{array}$ & Vivaldini \& Pires (2010) \\
analysis of suppliers' production and logistics data; Service level Agreements; & Chopra \& Meindl (2009) \\
Codification & Measurement and Analysis of performance of the service level; development et al. (2009) & Ballou (2003) & Reyes \& Giachetti (2010) \\
Supplier Management & of operations and integrated and responsive management; management of & Daugherty et al. (2011) \\
Code: GFOR1 & $\begin{array}{l}\text { supplier relationships; development of suppliers; outsourcing policies well } \\
\text { GFOR 1.1 to GFOR 1.21 }\end{array}$ & $\begin{array}{l}\text { suppliers; performance of suppliers; well-defined collaboration policies with key } \\
\text { suppliers. }\end{array}$ & \\
\hline
\end{tabular}

Source: Elaborated by the authors (2015). 
of Transport, the National Association of Railroad Transport, Concessionaires and also based on data published in journals dealing with the logistics sector.

The data analysis of the survey results was based on the analytical technique, explanation and description of maturity constructs. An exploratory survey with a non-probabilistic sample was carried out. Key variables of the maturity of LSPs, expressed in the $\mathrm{S}(\mathrm{CM})^{2}$ model were used. A data protocol was formalized, with the procedures to be followed and applied by each element (respondent) of the survey sample.

A professional manager with extensive experience in LSP, being in his/her current post for more than five years, should fulfill the questionnaires.

The research variables definition was guided by the following aspects: i) Place of research: Brazil; ii) Units of analysis: Concessionaires of the rail freight subsector (classified in this study as LSP); iii) lssues based on best practices identified in the literature; iv) Methodology: Quanti-Qualitative research, using the technical procedure of an exploratory survey, by means of the instrument of data collection using a questionnaire and documental research; v) Sources of information: Manager of the concessionaires, with extensive experience in the company, the concessionaires themselves through the communication sector, trade magazines, public records, and so forth; vi) Parties incorporated: functional areas of each concessionaire.

Questions i) to xiii) were a semi-open type, to contextualize information about the concessionaires taking part in the study. Table 3 shows the practices that are important for evaluating the first group of questions.

The variables were numbered from 1 to 6 , in each code representative of each vision. The first four letters of the code are the abbreviation (in Portuguese) of the variable or vision assessed in each case. The first number after this abbreviation is related to which of the six visions the questionnaire is evaluating $(1,2,3,4,5,6)$. The remaining digits refer to the numbering sequence in the questionnaire. For example, the code GSMD6.170 is question number 170 of the questionnaire, part of the group of Management of Performance Measurement Systems, considered Group 6, thus formalizing the code of Question GSMD6.170.

An email account to manage the information flow was created, and a database was established.

The assessment and analysis of the overall level of maturity of each LSP and the scores in each vision of the $\mathrm{S}(\mathrm{CM})^{2}$ were generated from the simple arithmetic average of the scores awarded to the best practices, in each group of issues of the questionnaire. This criterion is considered for the visions that vary the scores among the five levels, thus forming a pattern of non-constant averages.

A second alternative criterion was used to determine the maturity level of the visions that presented constant patterns around the maximum average score equal to 4. This mean that all practices related to the levels assessed are fully available. For example, the case of vision GPSL2 of the LSP A, which has a maturity level of 4 (Collaborative), since all practices of this vision, from levels 1-4 are shown to be fully available. Thus, the simple arithmetic average (3.89) does not accurately reflect the true level of maturity of the vision.

The association between the scores of the likert scale $(1,2,3,4)$ and $\mathrm{S}(\mathrm{CM})^{2}(1,2,3,4,5)$ levels are not symmetrical and determining level 5 is conditioned to the situation of the practices being fully in place in all matters of the vision assessed. If the alternative criterion did not exist, it would be impossible to have one of the visions and consequently, for a LSP to reach maturity level 5 . Therefore, the association of the responses to the levels is dependent on two distinct criteria given the constant and non-constant pattern that the score can take.

The points on the likert scale adopted, assigned to the scores on the existence of best practices in the LSP are: 1 - no or non- existent, 2 - implementation studies underway, 3 - partially existing; 4 - yes or existing.

The questions were drawn up following the logic of the best practices for each vision and at the evolutionary $\mathrm{S}(\mathrm{CM})^{2}$ levels of maturity. The criterion adopted and contained in the $\mathrm{S}(\mathrm{CM})^{2}$ model is that of rounding down to the nearest integer lower in the scale. For example, the average score in the questions on code GFOR1.3 - 1.7 of LSP A was 3.60. As the values of the scale proposed assume only integer and ordered values, taking into account that the model specifies that if a level reaches the maximum score, improvements should be made so as to advance to the next level. The final score is 3 , and the fraction 0.60 expresses that among the practices listed at that level, some still do not exist (1), are in the process of studies for implementation (2) or partially exist (3).

As mentioned above, the score on each level $\mathrm{S}(\mathrm{CM})^{2}$ is simply calculated by adding the scores given by the respondent questions for that level $i$ $(1,2,3,4,5)$ divided by the total components issues $m$. Then add up all of the scores assigned issues group ( $j$ ) for all levels and divided by the $M$ number of questions from the group, obtaining the average maturity group. The procedure is repeated for each of the six visions, according to the following equation and example in Table 4, Equation 1: 
Table 4. Evaluation Group Supplier Management.

\begin{tabular}{|c|c|c|c|c|c|}
\hline $\begin{array}{c}\text { Variable Control } \\
\text { Supplier } \\
\text { Management } \\
\text { Code: GFOR1 }\end{array}$ & Level S(CM) ${ }^{2}$ & $\begin{array}{l}\text { Number of issues } \\
\text { per subgroup }\end{array}$ & Score & Average & Rank in Likert scale \\
\hline GFOR 1.1-1.2 & 1-Undefined & 2 & 8 & 4 & 4 \\
\hline GFOR 1.3-1.7 & 2-Collaborative & 5 & 18 & 3.60 & 3 \\
\hline GFOR 1.8-1.11 & 3-Managed & 4 & 12 & 3 & 3 \\
\hline GFOR 1.12-1.15 & 4-Collaborative & 4 & 13 & 3.25 & 3 \\
\hline GFOR 1.16-1.21 & 5-Lidership & 6 & 23 & 3.83 & 3 \\
\hline Total & $\begin{array}{l}\text { Level } 3 \\
\text { Managed }\end{array}$ & 21 & 74 & $74 / 21=3.52$ & \\
\hline
\end{tabular}

Source: Elaborated by the authors (2015).

$\sum_{i=1}^{5} \sum_{j=1} \frac{G F O R i j}{\frac{m}{M}}+\sum_{i=1}^{5} \sum_{j=2} \frac{G P S L i j}{\frac{m}{M}}+$

$\sum_{i=1}^{5} \sum_{j=3} \frac{\text { GETAij }}{\frac{m}{M}}+\sum_{i=1}^{5} \sum_{j=4} \frac{G R H U i j}{\frac{m}{M}}+$

where:

$\sum_{i=1}^{5} \sum_{j=5} \frac{G S I T i j}{\frac{m}{M}}+\sum_{i=1}^{5} \sum_{j=6} \frac{G S M D i j}{\frac{m}{M}}$

$i j \rightarrow i$-level evaluated in the $j$-group;

$m \rightarrow$ number of questions of level $i(i=1,2,3,4,5)$;

$\mathrm{M} \rightarrow$ number total questions of group $j(j=1,2,3,4,5,6)$;

To obtain the overall maturity level of the LSP associated with the mean scores assigned to the visions, the following relationship was adopted:

- Median score $=1$, NO or non-EXISTENT $\rightarrow$ Maturity level: 1 - Undefined;

- Median score $=2$, IMPLEMENTATION STUDIES UNDERWAY $\rightarrow$ Maturity Level: 2 - Defined;

- Median score = 3, PARTIALLY EXISTING $\rightarrow$ Maturity Level: 3 - Managed;

- Median score $=4$, YES or EXISTING $\rightarrow$ Maturity Level: 4 - Collaborative;

- Median score $=4$, Yes or EXISTING IN 100\% OF THE PRACTICES OF ALL LEVELS OF A VISION $\rightarrow$ Maturity Level: 5 - Leadership.

\section{Evaluating the maturity of LSPs}

In this section the results are presented in two steps: first, a characterization of each LSP is undertaken to detect its particularities, the characteristics of the logistics operations and management systems (questions $i$-viii of the questionnaire and documentary research); thereafter, maturity is evaluated and analyzed, using the answers from the questionnaire at each level of the $\mathrm{S}(\mathrm{CM})^{2}$ in each of its six visions, from which the overall maturity of each LSP is determined. The data analyzed were collected between March 2011 and January 2012, by means of the questionnaire sent to the LSPs.

\section{1. $L S P A$}

According to data from characterizing LSP A collected in items $i$ ) to viii) of the questionnaire data from the National Transportation Terrestrial Agency (Agência Nacional de Transportes Terrestres, 2010a), and from the Statistical Yearbook of Transport (Agência Nacional de Transportes Terrestres, 2010b) for 2009 and from LSPs own data, its railroad concession and where it provides logistics services is in Southern Brazil. The portfolio of services serves clients who produce ceramic materials, coal, transport and ship containers and some agricultural products.

According to the manager who answered the questionnaire, the LSP is a medium-sized firm (classification - Banco Nacional de Desenvolvimento Econômico e Social, 2011) with an annual gross revenue in the range of $R \$ 16$ to $R \$ 90$ million. This manager is a planning manager, who had been in this post role for more than 10 years, and in the company for more than 15 years.

The maturity of each vision evaluated by the score obtained in the 164 questions answered by the LSP A manager is expressed by the radar chart in Figure 2. The overall maturity level measured was 3, Managed, obtained as a result of the average maturity of the six visions (Equation 1).

The finding that the practices of LSP A are at the Managed level is stronger when the scores at level 1 and 2 of all six evaluated visions are checked. They reach the maximum score in most questions (Likert scale rating $=4$ ), which means that the practices listed at that level do exist. It indicates that the existing 


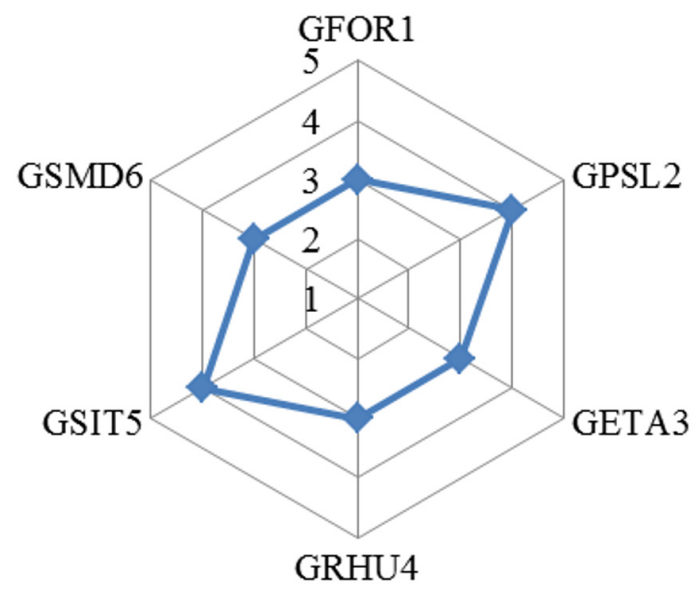

$\neg$ Maturity Levels

Figure 2. Maturity levels of the visions evaluated in LSP A. Source: Elaborated by the authors (2015).

processes with coverage in the six functional areas are documented and meet standard procedures. Besides, projects/programs have been implemented to identify, correct and improve problems in the provision of logistics services. Thus, it is verified that the processes are well understood and defined in their scope and management. Further, that the functional areas of the LSP are not functional silos, collaborate regularly and that production and management processes are relatively integrated.

The level of Managed indicates that the LSP A has practices for operations and the management of the provision of logistics services. It has defined procedures, which are clear about measuring how to manage, evaluate and improve internal processes and the management of the areas or departments regarding each vision. There is a functional integration of the areas, processes and management systems of the LSP. Therefore, there are still problems with collaboration and adoption of best practices with processes throughout the SCs in which the LSP offers its services and that lie beyond the limits of the company and leadership in the provision of logistics services - these are the levels to be achieved. Reyes \& Giachetti (2010) proposes drawing up maps of improvements for evolution from the level of average maturity. Figure 3 shows the relation between the average score for the practices of LSP A and its degree of overall maturity.

\section{2. $L S P B$}

The data presented in the characterization were obtained from the Questionnaire (items i to viii) and ANTT documents - National Agency of Road

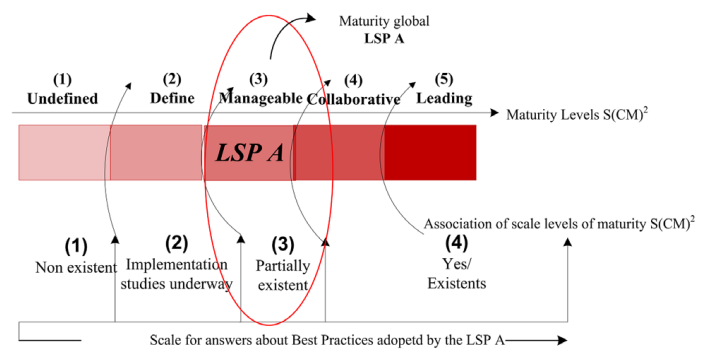

Figure 3. Global Maturity of LSP A. Source: Elaborated by the authors (2015).

Transportation (Agência Nacional de Transportes Terrestres, 2010a), Statistical Yearbook of Road Transport (Agência Nacional de Transportes Terrestres, 2010b) for 2009 and data from LSP B itself. It concentrates its railroad routes in the South Region, as does LSP A, but it extends its logistical services to the Midwest region and Paraguay.

LSP B is considered a small company, with gross revenues of between $\mathrm{R} \$ 2.4$ million and $\mathrm{R} \$ 16$ million (classification Banco Nacional de Desenvolvimento Econômico e Social, 2011). The LSPs portfolio of services serves 28 major customers. They are linked to agribusiness activities (inbound logistics of products from the port to producers and outbound logistics of agricultural products in reverse flow). The main products transported in relation to the former is fertilizer, lime, potassium, nitrate, phosphate, urea, diesel oil, and cement, and ammonia sulphate to cold-store companies. As to the end products derived from the activity of agribusiness, the largest volume of products transported in tons are the products of cold-store customers (refrigerated containers), agricultural commodities and derivatives such as soybean meal, soybeans grains, soybean oil, wheat and maize.

Two respondents filled the questionnaire applied to LSP B, being respectively, a Human Resources manager, who completed the group of questions related to the visions of Human Resources Management (GRHU4) and Management of Performance Measurement Sytems (GSMD6). He has been in the post for more than 5 years and in the company for more than 15 years. The second respondent was a production operator with more than 5 years in the post and in the company, who completed the remaining groups of questions (GFOR1, GPSL2, GETA3 and GSIT5).

The graph in Figure 4 shows that LSP B presented a maturity level of 2 in three of the six visions evaluated (GFOR 1; GSIT5; and GSMD6) and level 3 of maturity in the three other visions (GPSL2; GETA3; and GRHU4). When applying the methodology to obtain the overall level, which is the sum of the maturity levels in each vision times the number of views evaluated, there is a 


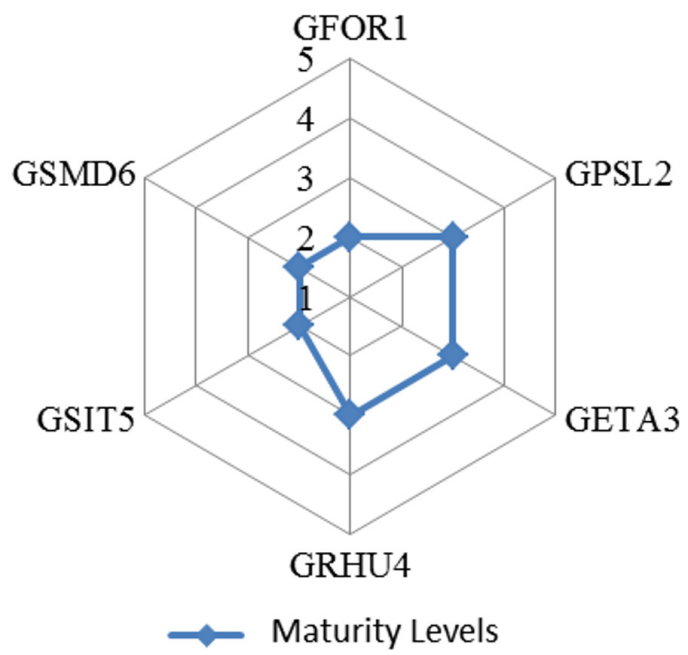

Figure 4. Maturity levels of the visions evaluated in LSP B. Source: Elaborated by the authors (2015).

total of 15 points $\left(\mathrm{GFOR} 1=2 ; \mathrm{GPSL}_{2}=3 ; \mathrm{GETA}_{3}=3\right.$; GRHU $4=3$; GSIT5 $=2$; and GSMD6 $=2$ ), indicating an average level of maturity of 2.50 . As the $S(C M)^{2}$ model adopts only entire levels, the overall maturity of LSPB is located at Level 2, Defined.

The frequency of responses that indicate the existence of best practice components of the 164 issues listed in the questionnaire was lower than 50\% for almost all levels of the six visions evaluated $(42.86 \%, 57.14 \%, 38.23 \%, 35.29 \%$, and $27.4 \%$ ) with the exception of level 2. The practices identified as non-existent (1) and in process of studies for implementation (2) exceeded the frequency of those identified as existing fully at all levels. At level 1 , the practices classified with scores of 1 and 2 add up to $35.69 \%(21.43 \%+14.26 \%)$, $19.05 \%$ at level $2,41.18 \%$ at level 3, 35.29\% at level 4 and 55\% at level 5 . This result strengthens the evidence obtained in the evaluation of the visions that the LSP B is in an organizational/logistic stage of immaturity, due to the high rate of non-existent best practices that range between 35\% and 55\% among the five levels of $\mathrm{S}(\mathrm{CM})^{2}$ levels.

The level of Defined indicates that the LSP B has practices in operations and management of the provision of logistics services with well-defined and well-understood procedures and processes. Therefore, there are still shortcomings and internal processes and areas or departments for each view that are not fully measured, managed, evaluated and improved. According to the $\mathrm{S}(\mathrm{CM})^{2}$, companies with a maturity level of 2 are still immature and priority improvements should be implemented to advance and develop the LSP to the next level, Managed (3).

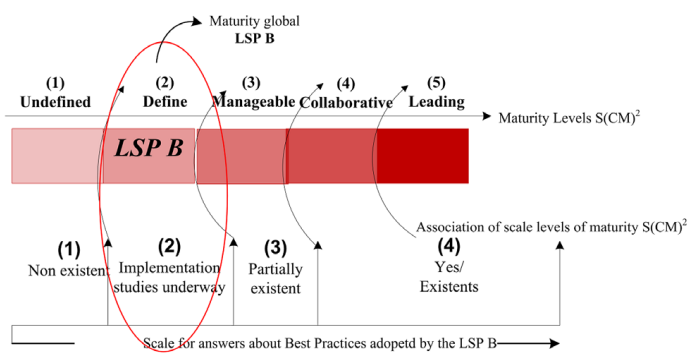

Figure 5. Global Maturity of LSP B. Source: Elaborated by the authors (2015).

According to Reyes \& Giachetti (2010), logistics organizations and those that run businesses in the supply chain begin to develop maturity because they have a large number of best practices that are used. Figure 5 shows the relation between the average score for the practices of LSP B and its degree of overall maturity.

\section{3. $L S P C$}

LSP C has a railroad concession in the Southeast region of Brazil, operating and controlling one of the biggest concessions regarding rail freight railroad in Brazil. Its logistics services cover the states of with the largest industrial concentration in the country (54\% of GDP): São Paulo, Rio de Janeiro and Minas Gerais, respectively. The production of LSP C is among the largest in the sector.

The data used for characterization were taken from items $i$ ) to viii) of the questionnaire, from the National Agency of Road Transport (Agência Nacional de Transportes Terrestres, 2010a), the Statistical Yearbook of Transport (Agência Nacional de Transportes Terrestres, 2010b) for 2009 and from LSP itself.

According to the data collected in the questionnaire, LSP $C$ is characterized as a large company, with gross revenues of over $\mathrm{R} \$ 300$ million per year (classification Banco Nacional de Desenvolvimento Econômico e Social, 2011). The LSP C services portfolio serves 100 main customers who demand general and containerized freight services. They are linked to the SC of minerals, agricultural commodities, steel/metallurgy, automotive, construction, chemical and petrochemical industries, and containers, etc.

To support the logistics of transporting the freight of the products mentioned, LSP C operates 17 rail terminals in the three states over which its rail network extends, some of these terminals being intermodal.

Regarding the intermodal integration operations, LSP C has a broad portfolio of integrated logistic services and solutions. These solutions include the 
physical-managerial type, such as planning and designing logistics, multimodality, and intermodality and defined transit time, besides its transport, stocking/storing and order processing. This integration occurs in the following ways: i) Railroad - Maritime (Cabotage), carried out by its logistics partners in the navigation sector, participating in inland logistics flows with origin-embarkation or destination-disembarkation in cabotage, exporting and importing cargoes; ii) Railroad - Railroad, service available via right of way, partnerships and connection of the network controlled by LSP C with other four other rail networks with coverage in the Southeast, South, Midwest and Northeast regions; iii) Road-rail, service offered in conjunction with LSP, third-party logistics operators and road carriers to serve the customer with a complete logistics solution, including door-to-door service.

The respondent to the questionnaire in LSP C was a general manager of Information Technology who completed the questions related to vision GSIT5; a general manager of Supplies completed the questions on the GFOR 1 vision; a general manager of Transportation Engineering completed the questions related to visions GPSL2 and GETA3 and, finally, a general manager of Services answered the group of GRHU4 and GSMD6 questions.

As presented in the radar graph in Figure 6, LSP C showed a maturity level of 4 in four of the six visions evaluated (GFOR1; GPSL2; GETA3; and GRHU4) and level 3 maturity in the two other visions (GSIT5 and GSMD6). When applying the methodology to obtain the overall level, there is a total of 22 points (GFOR 1 $=4 ; \operatorname{GPSL} 2=4 ; \operatorname{GETA} 3=4 ; \mathrm{GRHU} 4=4 ; \mathrm{GSIT} 5=3$; GSMD6 $=3) / 6$, which indicates an average maturity of 3.67. As the $\mathrm{S}(\mathrm{CM})^{2}$ adopts only entire levels, the overall maturity of LSP C is located at Level 3: Managed.

According to the script of proposed improvements in Reyes \& Giachetti (2010), some specific improvements with a focus on strategies and synergies with partner agents have to be made on the fourth level for all views. Especially in view of Information Systems and Management Technology, and Performance Measurement Systems, this improvement may be sufficient to LSP C mature to the level of cooperation.

The frequency of scores of 4 was above $80 \%$ of the level of Undefined to the Collaborative level - on level 1 the occurrence was 100\%; on level 2, 90.48\%; on level 3, 85.30\%; on level 4, 82.35\%. There was, therefore, a substantial decrease in level 5 of scores of 4, justified by the lower performance of frequency of these scores in the visions of GSIT5 and GSMD6.

When compared to the existence of best practices (4) for the responses obtained for LSP C, it presents the highest frequencies of these scores in relation to all other LSPs evaluated. The LSP C thus presented, just like the other LSPs evaluated, a lower performance in the visions of GSMD6 and GSIT5, but in a lesser degree of occurrence for scores of 3 (7.12\% at level 2; $14.70 \%$ at level 3 , and $11.76 \%$ at level 4 ), and scores of $2(2.38 \%$ at level 2 ; and $2.94 \%$ at level 4$)$ and scores of 1 with $2.94 \%$ at level 4 .

It is verified that the LSP C has superior degree maturity levels in its core visions, such as production of logistics services, transport and suppliers and, maturity that still needs to be developed in support visions such as technology management and especially in performance management. According to roadmap improvement $\mathrm{S}(\mathrm{CM})^{2}$, the priorities it should give to these two visions are improvements that can help the provider to position itself overall at more advanced levels of maturity, at which the core visions are already and also to the vision of human resources management. Figure 7 shows the relation between the average score for the practices of LSP C and its degree of overall maturity.

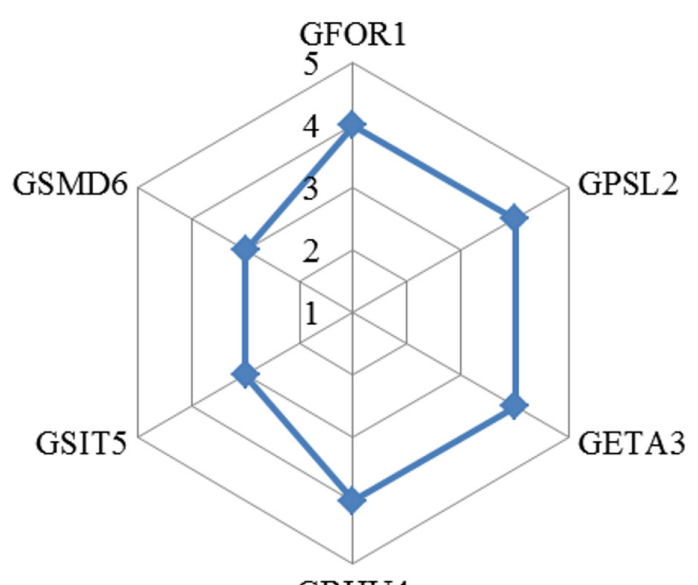

GRHU4

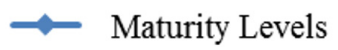

Figure 6. Maturity levels of the visions evaluated in LSP C. Source: Elaborated by the authors (2015).

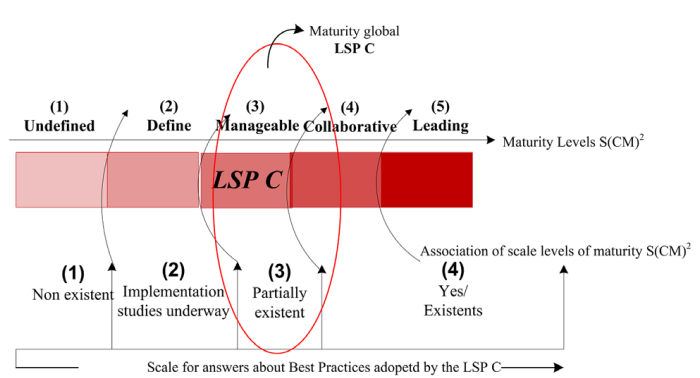

Figure 7. Global Maturity of LSP C. Source: Elaborated by the authors (2015). 


\section{Discussion}

The three LSPs that took part in the research are characterized as small to large companies, regulated by the regime of being a railroad concession and serving customers in very different supply chains, throughout the South and Southeast regions of Brazil.

Characterizing the LSPs also provides evidence for an assumption regarding the relationship between the development of management systems and the sophistication of operations with the LSPs maturity level. The evidence of this relationship is corroborated in the analysis of the overall scores and the respective maturity levels that each LSP investigated was found to have. This is verified when comparing the characterization data of LSP B with LSP C. The absence of these elements in the characterization of LSP B (Maturity Level: Defined), and their existence in the LSP C (Maturity Level: Managed) can be confirmed in the responses of both respondents, highlighting certain relationship between maturity and the development of best practices in operations and management of logistics agents discussed.

Regarding the overall level of maturity, two of the three LSPs (LSPs A and C) displayed intermediate levels of maturity, Managed; and LSP B presented level 2, Defined, which as per the definition of the $\mathrm{S}(\mathrm{CM})^{2}$ model, indicates that the organization is still at the immature stage in its life cycle.

The scores assigned by respondents to the questions representative of the component best practice of the six visions evaluated by the $\mathrm{S}(\mathrm{CM})^{2}$ model displayed results that follow two distinct patterns in this study: i) the most advanced maturity levels in the core functions/visions of all LSPs with regard to the Management of Transportation, Inventory, Warehousing, Processing of Orders and Management of the Provision of Logistics Services, there being evidence of a literal replication; ii) On the other hand, a non- homogeneous pattern of global maturity is characteristic when the maturity compared between the three LSP participants is analyzed.

This is mainly due to the fact that despite the levels assigned to the basic visions (GETA3 and GPSL2) being situated at an intermediate maturity, when compared with the other visions evaluated (GFOR1; GRHU4; GSIT5; and GSMD6), the results do not follow a defined pattern standard of replication. The literature defines this situation as common, since these agents develop best practices first in their core functions, such that thereafter they develop and advance in maturity in the support functions, thus formalizing the development process of the in-house maturity of the organization. The next step, according staged models presented in Table 2, would be to develop integration-collaboration and leadership practices in order to provide extended maturity in the SC, a situation in which none of the LSPs obtained a satisfactory performance and a common standard around the Collaborative (4) and Leadership (5) levels of the evaluation model $\mathrm{S}(\mathrm{CM})^{2}$.

The survey results showed that the maturity of the Rail Freight Logistic Service Providers varies depending on the size of the LSP. The LSP B, classified as a small, state-controlled company had the worst $\mathrm{S}(\mathrm{CM})^{2}$ level of maturity, this being 2-Defined. This situation, as per the definition of the levels of the model, indicates organizational immaturity. Nevertheless, when specifically the core functions (GPSL2 and GETA3) are analyzed, it is found to be at the Managed level. This situation provides evidence that at the levels of operational and tactical decisions that correspond to practices related to the short and medium term, this LSP adopts a large number of the best practices with respect to two visions and there is a degree of managerial sophistication, which places it at a level of the model where the literature indicates that the LSP begins to develop its maturity. Concerning the other visions, the LSP follows at levels of immaturity, in which the scores for these visions decrease, and thus the LSP requires developing best practices.

LSP A, classified as a medium-sized company, is situated at a more advanced level of maturity than LSP $\mathrm{B}$ and is established at level 3 of the evaluation model, called Managed. Logistics organizations classified at this level are considered by S(CM) ${ }^{2}$ as partially mature and should develop improvements in their practices spread across the different visions so that they may advance to higher levels of maturity. Once again, a pattern of better performance of maturity was found in the core visions of GPSL2 and GETA3, when compared to the other visions supporting the logistics business. In this case, the vision of Management Information and Technology Systems (GSIT5) was also established at the Collaborative level - the core functions have reached advanced levels of $\mathrm{S}(\mathrm{CM})^{2}$. In the LSP A, a logistics maturity (regarding the $\mathrm{S}(\mathrm{CM})^{2}$ core visions), as to organizational maturity (overall maturity of the six visions).

Finally, LSP C classified as a large-sized company was shown to be at an overall maturity level of Managed (3). Individually, it reached the level of Collaborative (4) in four of the six visions evaluated, with a frequency of $80 \%$ of scores of 4 . This means that the practices questioned are fully existent, since the undefined level up to the Collaborative level. The LSP is in a situation of developing best practices in a more advanced way than LSP A and B, while it requires to improve in the visions of supporting the Management of Information and Technology Systems 
and the Management of Measurement Systems in order to advance to the level of leadership and to focus on the best strategic practices that provide competitive advantage (Reyes \& Giachetti, 2010).

The results of the exploratory analysis on the maturity of the LSP of the rail freight sector show a disparity in the overall maturity levels of each LSP. They also present an indicative of relationship between the size of a LSP and its level of maturity. Therefore, at the same time, evidence was detected that in all three LSP participants, the two core functions that characterize basic logistics activities are at the Managed level. According to the definition given by $\mathrm{S}(\mathrm{CM})^{2}$, is the level at which logistics organizations are provided with relative maturity.

Considering that there are currently seven companies in Brazil actively engaged in the rail freight industry, of which three presented intermediate levels of maturity for the GPSL2 and GETA3 visions in the S(CM) ${ }^{2}$ evaluation, it is possible to induce that these agents are capable of sustaining the offer of logistics services and growing demand in the short term. Therefore, to strategic practices that promote integration and collaboration with service providers whose systems are in other modes, with customers and suppliers, should be given priority in terms of being developed so that this offer can meet foreseeable service levels and demands in the long term.

Finally, in all the visions analyzed, there is a need to adopt/implement long-term strategic practices that generate competitive advantages in all the visions evaluated. This will allow promoting organizational maturity and offering comprehensive services to support the growing demand and sophistication in the service levels and logistics solutions required by current and future customers in the SCs in which the LSPs render their services.

\section{Concluding remarks}

The purpose of this study was to carry out a diagnosis regarding the maturity of the service providers of rail freight logistics in Brazil. It was verified a gap in the literature regarding studies evaluating the maturity of LSP agents. It was also not found research related to evaluation of logistics service providers in freight railroad system. The model SC(M) ${ }^{2}$ by Reyes $\&$ Giachetti (2010) was chosen for application in this study, in function of its interdisciplinary character, evaluating multiple points of view.

By applying the Supply Chain Capability Maturity Model, it was verified that the maturity of the LSPs of the rail freight sector shows a disparity in the overall maturity levels of each one. It was also evidenced a potential relationship between the size of an LSP and its level of maturity. Therefore, for all participants of the study, the two core functions are in a level at which logistics organizations are provided with relative maturity (managed level).

The findings of this research can act as a reference point for the LSPs investigated, supporting the development of policies and strategies in light of improvements and adoption of best practices that lead to gains in competitiveness for both the LSPs, as well as the SCs that require their services. They also support the understanding of the relationship between the development in terms of best practices in the management of the six managerial functions (supplier management, production management of logistics services, transport management, management of systems and technology information, human resource management and performance management) and the level of maturity of the LSPs investigated. As to further studies that ought to be undertaken, consideration should be given to developing a model that encloses, specifically, the logistic maturity evaluation of organizations that have their outputs based on logistics services.

\section{References}

Agência Nacional de Transportes Terrestres. (2010a). Relatório Anual de Acompanhamento das Concessões Ferroviárias: Ano 2009. Brasília.

Agência Nacional de Transportes Terrestres. (2010b). Anuário Estatístico dos Transportes Terrestres: AETT 2009. Brasilia.

Associação Nacional dos Transportadores Ferroviários. (2010). Balanço do Transporte Ferroviário de Cargas 2009: Coletiva de Imprensa. Brasília.

Bai, C., \& Sarkis, J. (2013). Flexibility in reverse logistics: a framework and evaluation approach. Journal of Cleaner Production, 47, 306-318. http://dx.doi.org/10.1016/j. jclepro.2013.01.005.

Ballou, R. H. (2003). Business logistics: Supply Chain Management (5th ed.). New Jersey: Prentice Hall.

Banco Nacional de Desenvolvimento Econômico e Social. (2011, September 6). Normas reguladoras do produto BNDES automático (Circular, № 3406). Rio de Janeiro.

Bowersox, D. J., Closs, D. J., \& Cooper, M. B. (2009). Supply Chain Logistics Management. New York: McGraw-Hill.

Capability Maturity Model Integrated. (2011). Standard CMMI ${ }^{\circledR}$ Appraisal Method for Process Improvement (SCAMPISM) $A$ (Version 1.3: Method Definition Document). Pittsburgh: Carnegie Mellon University. Version 1.3: Method Definition Document.

Chopra, S., \& Meindl, P. (2009). Supply Chain Management: strategy, planning and operation (4th ed.). New Jersey: Prentice Hall

Christopher, M. (2007). Logistics \& Supply Chain Management: creating value-adding networks (3rd ed.). New Jersey: Prentice Hall. 
Colicchia, C., Marchet, G., Melacini, M., \& Perotti, S. (2013). Building environmental sustainability: empirical evidence from logistics service providers. Journal of Cleaner Production, 59, 197-209. http://dx.doi.org/10.1016/j. jclepro.2013.06.057.

Cooke-Davies, T. J., \& Arzymanow, A. (2003). The maturity of project management in different industries: an investigation into variations between project management models. International Journal of Project Management, 21(6), 471478. http://dx.doi.org/10.1016/S0263-7863(02)00084-4.

Crosby, P. B. (1979). Quality is free: the art of making quality certain (Vol. 94). New York: McGraw-Hill.

Daugherty, P. J., Chen, C., \& Ferrin, B. C. (2011). Organizational structure and logistics service innovation. International Journal of Logistics Management, 22(1), 26-51. http:// dx.doi.org/10.1108/09574091111127543.

Ellram, L., Tate, W., \& Billington, C. (2008). Offshore outsourcing of professional services: a transaction cost economic perspective. Journal of Operations Management, 26(2), 148-163. http://dx.doi.org/10.1016/j.jom.2007.02.008.

Estampe, D., Lamouri, S., Paris, J., \& Brahim-Djelloul, S. (2013). A framework for analysing supply chain performance evaluation models. International Journal of Production Economics, 142(2), 247-258. http://dx.doi.org/10.1016/j. ijpe.2010.11.024.

Flint, D. J., Larsson, E., Gammelgaard, B., \& Mentzer, J. T. (2005). Logistics innovation: A customer value-oriented social process. Journal of Business Logistics, 26(1), 113-147. http://dx.doi.org/10.1002/j.2158-1592.2005.tb00196.x.

Forza, C. (2002). Survey research in operations management: a process-based perspective. International Journal of Operations \& Production Management, 22(2), 152-194. http://dx.doi.org/10.1108/01443570210414310.

Frederico, G. F., \& Martins, R. A. (2012). Model for alignment between performance measurement systems and maturity of Supply Chain Management. Gestão \& Produção, 19(4), 857871. http://dx.doi.org/10.1590/S0104-530X2012000400014.

Fugate, B. S., Mentzer, J. T., \& Stank, T. P. (2010). Logistics performance efficiency, effectiveness and differentiation. Journal of Business Logistics, 31(1), 43-62. http://dx.doi. org/10.1002/j.2158-1592.2010.tb00127.x.

Giachetti, R. E. (2010). Design of enterprise systems: theory, architecture, and methods. Boca Raton: CRC Press.

Goldenson, D., \& Gibson, D. (2003). Demonstrating the impact and benefit of CMMI: an update and preliminary results (Special Report CMU/SEI-2003- SR-009). Pittsburgh: Carnegie Mellon University.

Guarnieri, P., Sobreiro, V. A., Nagano, M. S., \& Serrano, A. L. M. (2014). The challenge of selecting and evaluating third-party reverse logistics providers in a multicriteria perspective: a Brazilian case. Journal of Cleaner Production, 1, 1-11. http://dx.doi.org/10.1016/j.jclepro.2014.05.040.

Hofmann, E., \& Lampe, K. (2013). Financial statement analysis of logistics service providers: ways of enhancing performance. International Journal of Physical Distribution \& Logistics Management, 43(4), 321-342. http://dx.doi.org/10.1108/ 1JPDLM-08-2012-0229.

Huemer, L., \& Furlan, A. (2013). Value logic interactions: perspectives on logistics service provider-client relationships. Mercati e Competitivitá, 17(1), 35-51. http://dx.doi. org/10.3280/MC2013-001004.

Kafa, N., Hani, Y., \& Mhamedi, A. (2014). A fuzzy multi criteria approach for evaluating sustainability performance of third - party reverse logistics providers. Advances in Production Management Systems, 439, 270-277. http:// dx.doi.org/10.1007/978-3-662-44736-9_33.

Knemeyer, M., \& Murphy, P. R. (2004). Evaluating the performance of third-party logistics arrangements: a relationship marketing perspective. Journal of Supply Chain Management, 4O(1), 35-51. http://dx.doi.org/10.1111/j.1745-493X.2004.tb00254.x.

Kudla, N. L., \& Klaas-Wissing, T. (2012). Sustainability in shipperlogistics service provider relationships: A tentative taxonomy based on agency theory and stimulus-response analysis. Journal of Purchasing and Supply Management, 18(4), 218-231. http://dx.doi.org/10.1016/j.pursup.2012.04.001.

Lai, K. (2004). Service capability and performance of logistics service providers. Transportation Research Part E: Logistics and Transportation Review, 40(5), 385-399. http://dx.doi. org/10.1016/j.tre.2004.01.002.

Lang, A. E. (2007). As ferrovias no Brasil e avaliação econômica de projetos: uma aplicação em projetos ferroviários. (Dissertação de mestrado). Departamento de Engenharia Civil e Ambiental, Faculdade de Tecnologia, Universidade de Brasília, Brasília.

Leuschner, R., Carter, C. R., Goldsby, T. J., \& Rogers, Z. S. (2014). Third-party logistics: a meta-analytic review and investigation of its impact on performance. Journal of Supply Chain Management, 50(1), 21-43. http://dx.doi. org/10.1111/jscm. 12046 .

Lieb, K. J., \& Lieb, R. C. (2010). Environmental sustainability in the third-party logistics (3PL) industry. International Journal of Physical Distribution \& Logistics Management, 40(7), 524-533. http://dx.doi.org/10.1108/09600031011071984.

Lieb, R. C., \& Lieb, K. J. (2008). Why 3PLs need to build their brand? Supply Chain Management Review, 12(8), 46-52.

Lockamy III, A., \& McCormack, K. (2004). The development of a Supply Chain Management process maturity model using the concepts of business process orientation. Supply Chain Management: An International Journal, 9(4), 272-278. http://dx.doi.org/10.1108/13598540410550019.

McCormack, K., Ladeira, M. B., \& Oliveira, M. P. V. (2008). Supply chain maturity and performance in Brazil. Supply Chain Management: An International Journal, 13(4), 272-282. http://dx.doi.org/10.1108/13598540810882161.

McCormack, K., Willems, J., van den Berg, J., Deschoolmeeter, D., Willaert, P., Štemberger, M. 1., Škrinjar, R., Ladeira, M. B., Oliveira, M. P. V., Vuksic, V. B., \& Vlahovic, N. (2009). A global investigation of key turning points in business process maturity. Business Process Management Journal, 15(5), 792-815. http://dx.doi.org/10.1108/14637150910987946.

Miguel, P. A. C., \& Ho, L. L. (2012). Levantamento tipo Survey. In P. A. C. Miguel (Coord.), Metodologia de pesquisa em Engenharia de Produção e Gestão de Operações (2nd ed., Série Campus-Abepro). Rio de Janeiro: Elsevier.

Min, H., \& Joo, S. J. (2006). Benchmarking the operational efficiency of third party logistics providers using data envelopment analysis. Supply Chain Management: An International Journal, 11(3), 259-265. http://dx.doi. org/10.1108/13598540610662167.

Poirier, C. C., Quinn, F. J., \& Swink, M. L. (2009). Diagnosing greatness: ten traits of the best supply chains. Fort Lauderdale: J. Ross Publishing.

Project Management Group. (2003). Boost the bottom line with supply chain best practices. Signals of Performance, 4(1). Retrieved in 10 November 2014, from http://www. pmgunited.com/ 
Reyes, G. R., \& Giachetti, R. (2010). Using experts to develop a supply chain maturity model in Mexico. Supply Chain Management: An International Journal, 15(6), 415-424. http://dx.doi.org/10.1108/13598541011080400.

Rossi, C. (2013). Custos logísticos voltam a crescer no País, diz pesquisa. Revista Exame. Retrieved in 5 November 2014, from http://exame.abril.com.br/economia/noticias/ custos-logisticos-voltam-a-crescer-no-pais-diz-pesquisa

Stevens, G. C. (1989). Integrating the supply chain. International Journal of Physical Distribution \& Logistics Management, 19(8), 3-8. http://dx.doi.org/10.1108/EUM0000000000329.

Sturm, R., Morris, W., \& Jander, M. (2002). Service level agreement. Campus: Rio de Janeiro.

Trkman, P., Ladeira, M. B., Oliveira, M. P. V., \& McCormack, K. (2012). Business analytics, process maturity and supply chain performance. In Proceedings of the Business Process Management Workshops. Berlin, Germany.

Vivaldini, M., \& Pires, S. R. l. (2010). Operadores logísticos: integrando operações em cadeias de suprimentos. São Paulo: Atlas.

Vivaldini, M., Pires, S., \& Souza, F. B. D. (2013). Collaboration and competition between 4PL and 3PL: a study of a fastfood supply chain. Journal of Operations and Supply Chain Management, 1(2), 17-29. http://dx.doi.org/10.12660/ joscmv $1 \mathrm{n} 2 \mathrm{p} 17-29$.
Wagenstetter, N., Kalogerakis, K., Kersten, W., \& Herstatt, C. (2013). A new approach to innovation for logistics service providers based on inventive analogies. In Proceedings of the IEEE Technology Management Conference \& 19th ICE Conference. The Hague, The Netherlands.

Wanke, P. F., Arkarder, R., \& Hijjar, M. F. (2007). Logistics sophistication, manufacturing segments and the choice of logistics providers. International Journal of Operations \& Production Management, 27(5), 542-559. http://dx.doi. org/10.1108/01443570710742401.

Wettstein, T., \& Kueng, P. A. (2002). Maturity model for performance measurement systems. Management, Information Systems, 113-122. http://dx.doi.org/10.2495/MIS020111.

Zacharia, Z. G., Sanders, N. R., \& Nix, N. W. (2011). The emerging role of the third-party logistics provider (3PL) as an orchestrator. Journal of Business Logistics, 3(1), 4054. http://dx.doi.org/10.1111/j.2158-1592.2011.01004.x.

\section{Acknowledgements}

This study is part of a research program funded by the Brazilian Research Council (CNPq). 